\title{
Comparison of Live Coral Cover in Central and South Bangka
}

\author{
Mu'alimah Hudatwi and Umroh \\ Department of Marine Science, Faculty of Agriculture, Fisheries and Biology, Bangka Belitung \\ University, Bangka Belitung 33172, Indonesia \\ Email: alihudatwi@gmail.com
}

\begin{abstract}
Coral reef ecosystem has many biological, ecological, and economical functions to the universe. This ecosystem provides shelter, food, and home for many marine organisms and together they perform diverse and rich ecosystem. However, this diverse ecosystem is very susceptible to environmental change, such as climate change, ocean acidification, and other anthropogenic impact. When reef-building coral could not stand with harsh condition they will eventually die. We assume that anthropogenic stressor such as turbidity, terrestrial runoff, and sedimentation is the main problem here, because of high number of tin mining activities. Bangka and Belitung Islands are huge tin producer and has been exploited heavily by the legal and illegal miner company. The purpose of this study is to investigate the live coral cover in Central and South Bangka by using the line intercept transect to calculate the live coral, died coral, and algae in each stations. The results showed that the coral cover in Central Bangka and South Bangka has fair condition $125-40 \%$ of live stony coral). Value of live and dead coral cover was $40 \%$ with Semujur and Ketawai represent the coral cover in Central Bangka. While South Bangka has slight (1-2\%) difference of live coral, dead coral, and algae cover. High number of dead coral mainly composed by dead coral overgrown by algae, allegedly caused by high turbidity and sedimentation from the anthropogenic stressor.
\end{abstract}

Keywords: coral reef, coral cover, died coral, sedimentation

\section{Abstrak \\ Perbandingan Tutupan Karang Hidup di Bangka Tengah dan Selatan}

Ekosistem terumbu karang mempunyai fungsi biologi, ekologi, dan ekonomi yang bermanfaat bagi manusia. Ekosistem ini menyediakan tempat berlindung, makanan, dan rumah bagi organisme laut dan membentuk suatu ekosistem yang kaya dan beragam. Namun, ekosistem ini sangat rentan terhadap perubahan lingkungan, sepertiiklim, asidifikasi, dan dampak lain yang dilakukan manusia. Ketika terumbu karang tidak mampu bertahan dengan perubahan lingkungan yang ekstrim mereka akan mati. Kami menduga bahwa dampak antropogenik seperti turbiditas, runoff dari darat, dan sedimentasi merupakan penyebab utama kerusakan terumbu karang, karena banyaknya aktivitas penambangan. Kepulauan Bangka belitung adalah penghasil timah terbesar dan telah dieksploitasi oleh penambang timah legal maupun ilegal. Tujuan dari penelitian ini adalah untuk mengetahui tutupan karang hidup di Provinsi Bangka Tengah dan Bangka Selatan dengan menggunakan metode traksek garis. Hasil menunjukkan bahwa terumbu karang di Bangka Tengah dan Selatan termasuk kategori sedang (25- 40\% tutupan karang). Tutupan karang hidup dan karang mati di Bnagka Tengah sebesar $40 \%$ dari hasill pengamatan di Semujur dan Ketawai. Sedangkan nilai tutupan karang hidup, karang mati, dan alga di Bangka Selatan mempunyai angka perbedaan yang rendah (1-2\%). Tingginya tutupan karang mati tersusun oleh karang mati yyang ditumbuhi alga yang disebabkan oleh turbiditas dan sedimentasi.

Kata Kunci: karang mati, terumbu karang, tutupan karang, sedimentasi

\section{INTRODUCTION}

Coral reef is highly productive ecosystem that provides and supply the habitat structure for many organisms as a feeding, nursery and spawning ground (Craik et al., 1990). The rich ecosystem provides food and livelihood for millions of people around the world living in tropical zone. However this mutual association is very sensitive to 
environmental changing lead to loss of healthy coral cover in the ocean. There are natural and anthropogenic stressor as the key role for the coral reef mortality. Major anthropogenic risk factors include water pollution from terrestrial runoff, high turbidity, and sedimentation. High exposure of sediments from the river and offshore destructive activity will settle upon the coral colony. The continuous flow of sediments particle will smother the need of symbiodinium algae to obtained the sunlight and at last inhibit the photosynthesis process and lead to coral mortality. Weeber et al. (2012) reports the process of coral damage due to sedimentation. They mentioned the effect of organic rich-sediments on the several coral colonies on specific exposure time that can cause mortality. Environmental stressor will gradually decrease the coral reef ecosystem.

Bangka Island is heavily explored for tin mining activity, the tin miner dig the land and sucking the seawater to search for the metal. The mining activity was started long ago since 1711 in Bangka and 1852 in Belitung (Susanto, 2015) and still continues until now. The numbers of off-shore mining are more than 70 floating ships in 2015 (Mongabay, 2015). The off-shore mining will reduce the water quality, decline the marine ecosystem, and destruct the habitat of marine organism. The mining activity plus the runoff from the land will eventually kill the coral reef ecosystem. This study aimed to measure the coral cover in Bangka Island (central and south) by considering these question: 1. How many percentage of live stony coral cover in Central Bangka comparing in the South area? 2. What is the major threat of coral loss in Bangka?

\section{MATERIALS AND METHODS}

This study was conducted at Central Bangka and South Bangka in August 2017, 4 stations in each region. Comparing the total coral cover in each province. Bangka Island is part of tin belt deposits, many tin mining activities carried out to explore the tin deposits both from the land and seawater. Some research also showed the impact of high sedimentation on coral reef community (Weeber et al., 2012). To analyze the reef loss, we conduct a 50 meter transect using line Intercept Transect (English et al., 1994) survey parallel to the shoreline in each stations. We analyze the coral compositions by calculating the value of live stony coral, dead coral, algae, other, and abiotic factors. The location was showed in Table 1.

\section{RESULTS AND DISCUSSION}

The survey showed that total live stony coral cover (Figure 1) in Central Bangka $(40.06 \%)$ is higher than South Bangka (29.23\%). We select Semujur and Ketawai Island as a selective location from Central Bangka, where both islands located quite far from the main island (7-8km). The benthic condition of both islands nearly the same, seen from the components of live coral, dead coral, and the algae. The number of dead coral in Semujur is $36.89 \%$ (an average from 2 transect points), mainly composed by dead coral overgrown by algae. Semujur and Ketawai is popular tourist destination in Bangka especially during the weekend. The local boat transportation from Kurau harbor is available everyday depending on the tide situation. The harbor is busy of trading activity from the fisherman catch and also transportation to nearby islands. The harbor is connected to the Kurau river, busy dock especially during the east monsoon. The community performed tin mining activity in the upstream area which create sedimentation in the downstream river. Kurau river transport the sediment particles from the mining work and household to the estuary and finally sttled in the sea. The high sedimentation in the downstream area will generate the river siltation that interfere the boat to enter or leave the harbor, ultimately will disturb the fish trading activity.

Compare with Semujur, Ketawai has $43.14 \%$ of dead coral also composed by overgrown algae. Ketawai has higher dead coral cover rather than live stony coral indicating that the area needs to be managed appropriately based on the resent condition. Adibrata (2013) mentioned the overall condition of reef coral cover in north, east, south, and west of Ketawai. In the east side, the coral cover in in good condition (67.8\%) and recommended for tourism activities like snorkeling or diving, while south and north area has fair-good coral cover. The 
most severe damage located in the west side $(40.9 \%)$ because of sedimentation flow from Bangka Island especially during rainy season where the particulate matter drifted to other location. This research was correspondent with his to immediately take an action particularly the west side area as a rehabilitation zone to restore the reef community .

From 8 stations surveyed, both the highest and lowest live coral cover located in South Bangka. From 4 location sampled, the coral composition in each station is varied. The highest live coral cover was in St.7 $(75,8 \%)$ located in Seniur Island, while the lowest coral cover in St.6 (4.5\%). St.7 has $23.32 \%$ of dead coral with rest of composition is abiotic factor, based on Gomez and Yap (1988), St.7 has excellent category of live stony coral condition. In the contrary, St.6 was dominated by algae for $60.26 \%$, live coral only $4.2 \%$. Related with the previous explanation, the competing alga- coral community over the place to live and grow is highly discussed, the stronger will win the space and take over the occupied land Swierts and Vermeij, 2016). The also mentioned that the cause of space take over is due to overfishing of herbivorous fish and also sedimentation that cover the coral colony and lead to mortality. As algae grow in abundance, they can actively overgrow live stony corals or passively take over space after corals have died. St. 5 has highest dead coral number $51.52 \%$ compare to live coral cover $19.72 \%$ algae $25.62 \%$. The dead coral mainly because of high sedimentation from the mainland see figure 2 to compare the coral condition in Central Bangka and South Bangka. The water has low visibility during the (survey (all stations is $\leq 2 \mathrm{~m}$ ) with high turbidity and sedimentation, as suspected of causing coral mortality. The runoff from terrestrial and also shoreline has nutrient rich matter that after landing in live coral surface will block the symbiotic algae activity and gradually kill the coral. Weber et al. (2012) explained the mechanisms of coral stressed and died after exposed to runoff and sediment material. Erftemeijer et al. (2012) also confirm that turbidity and sedimentation could increase

Table 1. Coordinate of diving location to monitor the coral cover colony ( $\mathrm{St}=$ station)

\begin{tabular}{|c|c|c|c|}
\hline \multicolumn{4}{|c|}{ Central Bangka } \\
\hline \multicolumn{2}{|c|}{ Semujur } & \multicolumn{2}{|c|}{ Ketawai } \\
\hline Station 1 & Station 2 & Station 3 & Station 4 \\
\hline $02^{\circ} 09^{\prime} 36.8^{\prime \prime} \mathrm{S}$ & $02^{\circ} 08^{\prime} 47.6^{\prime \prime} \mathrm{S}$ & $2^{\circ} 15^{\prime} 46.76^{\prime \prime S}$ & $2^{\circ} 15^{\prime} 53.91 " \mathrm{~s}$ \\
\hline $106^{\circ} 18^{\prime} 58.8^{\prime \prime} \mathrm{E}$ & $106^{\circ} 17^{\prime} 45.6^{\prime \prime} \mathrm{E}$ & $106^{\circ} 19^{\prime} 19.83^{\prime \prime} \mathrm{E}$ & $106^{\circ} 20^{\prime} 17.26^{\prime \prime} \mathrm{E}$ \\
\hline \multicolumn{4}{|c|}{ South Bangka } \\
\hline Seniur & Ibul & Kelapan & \\
\hline Station 5 & Station 6 & Station 7 & Station 8 \\
\hline $02^{\circ} 50^{\prime} 18.8^{\prime \prime} \mathrm{S}$ & $02^{\circ} 52^{\prime} 53.7^{\prime \prime} \mathrm{s}$ & $2^{\circ} 51$ '2.91"S & $2^{\circ} 58^{\prime} 7.17^{\prime \prime S}$ \\
\hline $106^{\circ} 46^{\prime} 52.0^{\prime \prime} \mathrm{E}$ & $106^{\circ} 46^{\prime} 05.3^{\prime \prime} \mathrm{E}$ & $106^{\circ} 51$ '22.72"E & $106^{\circ} 42^{\prime} 34.09 " \mathrm{E}$ \\
\hline
\end{tabular}

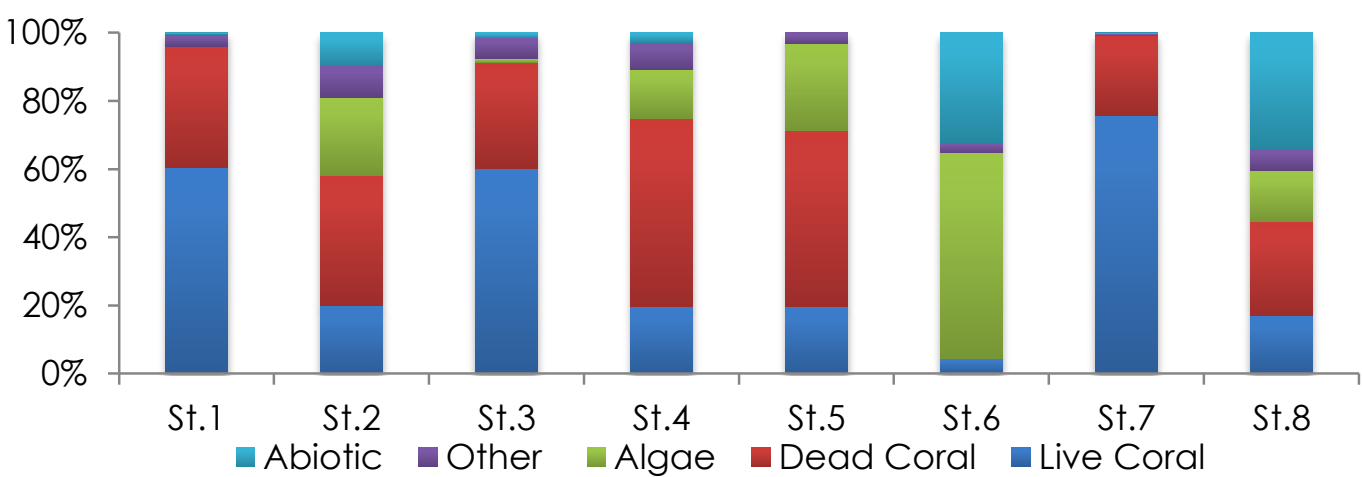

Figure 1. Histogram of benthic cover in Central and South Bangka. Indicated by the percentage of live coral, dead coral, algae (turf algae, macroalgae, corallious algae, halimeda, and algae assemblage), other (soft coral, sponges, zoanthids), and abiotic factor (sand, rock, rubble, silt). Note : St. $=$ Station 


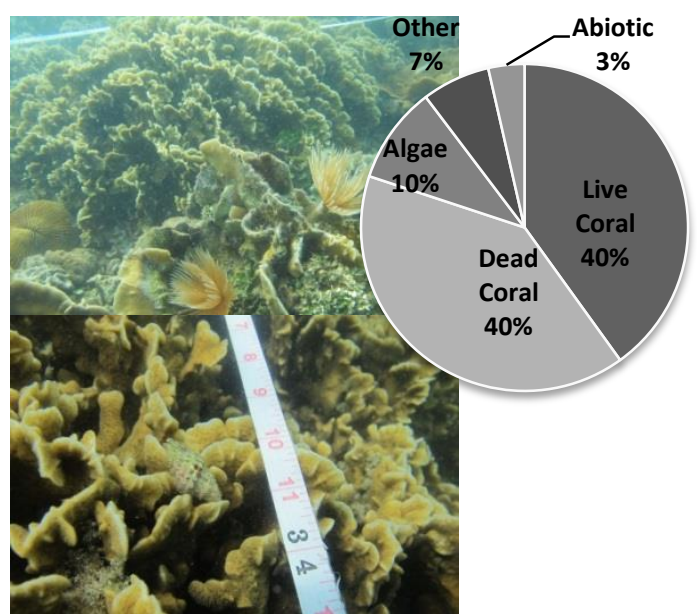

Central Bangka

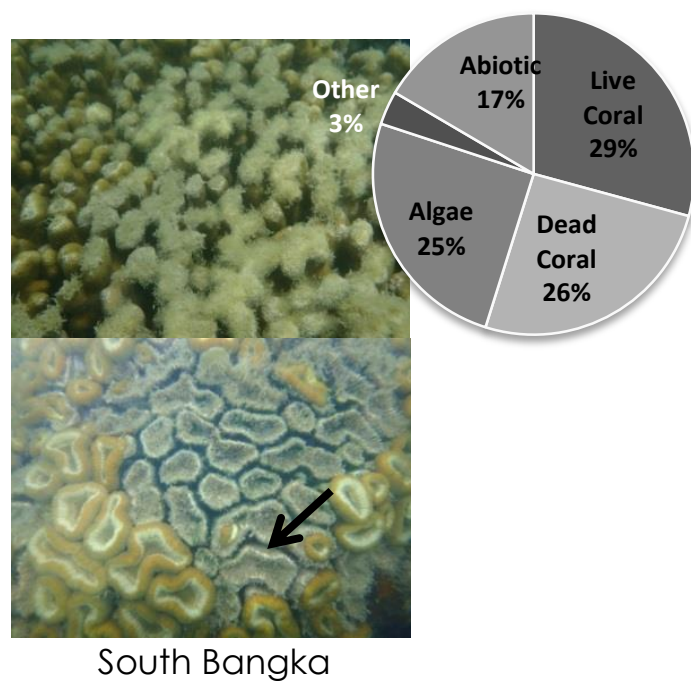

Figure 2. Left side, foliose coral cover in Central Bangka during LIT transect. Right side, high sedimentation covering the coral colony and inhibit the smbiotic algae to reach the sunlight. Right down showed the intracellular growth of coral polyp during high stress condition.

the loss of coral reef community by direct or indirect way. This sediment material may come from polluted river, terrestrial land, sewage, agricultural activity, and coastal dredging. Even though this St.5 located in small island, we assumed that the fine sediments particle was coming from the mainland particularly during rainy seasons when the material washed until neighboring island. St.8 has poor coral cover category based on the observation result, it has low number of dead coral, live cover, and algae composition, each $27.64,16.88 \%$, and $14.98 \%$.

\section{CONCLUSION}

In conclusion, the number of live coral cover in Central Bangka and South Bangka has fair coral condition with $25-40 \%$ caused by many environmental stressor particularly from destructive human activities. Therefore, the management plan needs to be implemented immediately.

\section{REFERENCES}

Adibrata, S. (2013). Evaluasi Kondisi Terumbu Karang di Pulau Ketawai Kabupaten Bangka Tengah. Jurnal Kelautan: Ind. J. Mar. Sci. Technol. 6(1):19-28.

Craik W., Kenchington R. \& Kelleher G. 1990. Coral-reef management. In: Coral Reefs (edited by Dubinsky) Ecosystems of the World 25, pp.453-467. Elsvier.
English, S., Wilkinson, C., \& Baker, V. 1994. (eds.) Survey Manual for Tropical Marine Resources. Australian Institute of Marine Science, Townsville.

Erftemeijer, P., Riegl, B., Hoeksema, B. \& Todd, P. 2012. Environmental impacts of dredging and other sediment disturbances on corals: a review. Mar. Poll. Bull. 64:1737-1765

Gomez, E.D. \& Yap, H.T. 1988. Monitoring Reef Condition. In: Kenchington, R. A., and B. E. T.Hudson.Coral Reef Management Handbook. UNESCO Regional Office for Science and Technology for Southeast Asia (ROSTSEA) . Jakarta

Mongabay, 2015. Desak Moratorium Tambang Laut, Ribuan Nelayan Bangka akan Geruduk Kantor Gubernur. Mongabay 28 December 2015, viewed 20 March 2018.

Swierts, T., \& Vermeij, M.J.A. 2016. Competitive interactions between corals and turf algae depend on coral colony form. Peer. J. 4: [e1984]

Susanto. 2015. Daerah kolong Timah di Bangka Belitung Dengan Data Satelit SPOT_6. Proceeding Semnastek 2015, 17 Novemver 2015, Jakarta.

Weber, M., de Beer, D., Lott, C., Polerecky, L., Kohls, K., Abed, R.M.M., Abed, T.G., Ferdelman, K.E. \& Fabricius. 2012. Mechanisms of damage to corals exposed to sedimentation. Proc. Natl. Acad. Sci. USA. $109(24)$ : E1558-67. 